\title{
Głoszenie Ewangelii życia i miłości misją rodziny
}

\section{PREACHING THE GOSPEL OF LIFE AND LOVE MISSION OF THE FAMILY}

Family in the Church's teaching is often referred to as a sanctuary of life and love. Love and life tell us about the identity of the family, her task and mission, which is to meet. The family built on the foundation of conjugal love of man and woman who draws from his only source - God, who is Love, has the task of witness to the love and serve life. The service life of the family is done by caring for the life of each of its members from the moment of conception until natural death, at every stage of its life and regardless of physical condition. The service life of the family also applies to care for the moral and spiritual life, as well as the perspective of a holy life and eternal life.

The service life and love in the family is also the proclamation of the Gospel of love and life, to which the family is called, through the testimony of everyday life and the proclamation of her mouth, first within the family, and then also to other families. The proclamation of the Gospel of love and life for the Christian family is something natural, as flows from its identity as a community of life and love.

Key words: marriage, family, love, life, Gospel, mission, society.

Zakończony Synod na temat powołania i misji rodziny w świecie współczesnym na nowo zwrócił uwagę na prawdę o tożsamości rodziny chrześcijańskiej, jej powołanie, misję i zadania, w tym szczególną 
misję głoszenia piękna powołania do życia małżeńskiego i rodzinnego, oraz misję głoszenia Ewangelii życia i miłości w codzienności zdarzeń. Zwrócił się do wszystkich rodzin świata, z ich radościami, trudnościami, ich nadziejami, gdyż czuł potrzebę, by podziękować Bogu za wielkoduszną wierność, z jaką wiele rodzin chrześcijańskich odpowiada na swoje powołanie i misję. Czynią to one $\mathrm{z}$ radością i wiarą, nawet wówczas, kiedy pielgrzymowanie rodzinne stawia je wobec przeszkód, nieporozumień i cierpień. Biskupi podkreślili, że rodzinom tym należy się uznanie, wdzięczność i zachęta całego Kościoła ${ }^{1}$, oraz wsparcie, by wypełniali dalej w radości swoje powołanie i misję.

To świadectwo jest dziś szczególnie ważne, gdyż małżeństwo jest dobrem, którego źródło znajduje się w dziele stworzenia, i które zakorzenione jest w naturze ludzkiej. Sakramentalne małżeństwo chrześcijańskie zaś wyraża także nowe życie zapoczątkowane przez Chrystusa Zmartwychwstałego ukazuje prawdę miłości małżeńskiej i jest w dzisiejszym świecie proroctwem zwiastującym w czytelny sposób to, czego naprawdę potrzebuje człowiek ${ }^{2}$. O tę tożsamość i realizację powołania, zadań i misji małżeństwa należy troszczyć się i wszelkimi sposobami wspierać komunię małżeńską i rodzinną wobec lęku i rozpaczy, która opanowuje serca wielu osób, gasnącej radości życia, braku szacunku i rosnącej przemocy ${ }^{3} \mathrm{w}$ życiu rodzinnym i społecznym. Rodzina musi stawić czoła wyzwaniu ochrony wartości życia ludzkiego, ekonomii wykluczenia i nierówności społecznej", wyrzucania na margines niektórych ludzi ${ }^{5}$ i być stale tym środowiskiem, w którym każdy ma swoje miejsce i jest chciany i kochany. Jako wspólnota miłości i życia rodzina staje w obronie wartości i godności człowieka przeciw „bałwochwalstwu pieniądza”, który ma służyć człowiekowi a nie nim rządzić ${ }^{6}$. Wielkim wyzwaniem dla dzisiejszej rodziny chrześcijańskiej jest ochrona, promocja i życie wartościami etycznymi i religijnymi ${ }^{7}$, które świat odrzuca bo są mu niewygodne

1 Relatio Synodi III Nadzwyczajnego Zgromadzenia Ogólnego Synodu Biskupów (18.10.2014), http://episkopat.pl/dokumenty/6230.1,quot_Relatio_Synodi_quot_ III_Nadzwyczajnego_Zgromadzenia_Ogolnego_Synodu_Biskupow.html (05.11.2011), n. 1 .

2 Papieska Rada ds. Rodziny, Przygotowanie do sakramentu matżénstwa (13.05.1996), n. 7.

3 Por. Franciszek, Evangelii gaudium (24.11.2013), n. 52.

4 Por. ibidem, n. 53.

5 Por. ibidem, n. 54.

6 Por. ibidem, n. 53-57.

7 Por. ibidem, n. 61-63. 
i wobec rozprzestrzeniającego się procesu sekularyzacji ${ }^{8}$. Chrześcijańska rodzina staje także wobec wyzwań, które płyną z jej wewnętrznego życia i struktury, a które zaczynają się już u jej podstaw i związane są z kruchością więzi, relacji i sposobu rozumienia miłości, często nazbyt „ulotnego", ale też z-indywidualizmu, który destabilizuje, deformuje i osłabia więzi rodzinne ${ }^{10}$, braku dialogu w rodzinie, wpływu środków przekazu, relatywistycznego subiektywizmu, konsumizmu, braku spojrzenia z miłością na drugiego człowieka, braku towarzyszenia duszpasterskiego najbardziej ubogim, czy trudność w przywróceniu mistycznego posłuszeństwa wiary w pluralistycznej scenerii religijnej ${ }^{11}$. Zjawiska te potwierdzają kryzys wartości moralnych, jak również utratę tożsamości małżeństwa i rodziny chrześcijańskiej. Tym stratom towarzyszy kryzys wartości wewnątrz samej rodziny, co prowadzi do takich konsekwencji jak spadek liczby zawieranych małżeństw, wzrost rozwodów, mentalność antykoncepcyjną i aborcyjną, pustkę duchową, brak satysfakcji i radości życia małżeńskiego i rodzinnego, a dalej do różnego rodzaju uzależnień, a nawet samobójstw wśród dzieci i młodzieży ${ }^{12}$. Wobec tych wyzwań staje się dziś jeszcze bardziej nagląca konieczność głoszenia prawdy o człowieku, małżeństwie i rodzinie, którą ukazuje nam Ewangelia, i oparcie relacji międzyludzkich, a szczególnie relacji małżeńskich i rodzinnych na miłości, która ma swoje źródło w Bogu bo „Bóg jest miłością” $(1 \mathrm{~J} 4,8)$ i pragnie szczęścia człowieka, gdyż powołał go z miłości i do miłości na wzór tej miłości, którą On sam żyje.

\section{Tożsamość małżeństwa i rodziny - wspólnota miłości i życia}

Osobowa tożsamość mężczyzny i kobiety - ich podobieństwo do Boga - to zdolność do życia w prawdzie i miłości - więcej nawet - to potrzeba prawdy i miłości jako wymiaru życia osobowego. Tego rodzaju potrzeba prawdy i miłości otwiera człowieka równocześnie na

8 Por. ibidem, n. 64-65. O wpływie sekularyzacji na życie małżeńskie i rodzinne zobacz też: Papieska Rada ds. Rodziny, Rodzina matżeństwo $i$ „wolne zwiazki” (26.07.2000), [w:] M. Brzeziński (red.), W trosce o dobro matżeństwa i rodziny, t. I, Dokumenty Papieskiej Rady ds. Rodziny, Lublin 2010, n. 31-32.

Por. Franciszek, Evangelii gaudium, n. 66.

Por. ibidem, n. 67.

Ibidem, n. 70.

Por. Papieska Rada ds. Rodziny, Przygotowanie do sakramentu matżeństwa, n. 12. 
Boga oraz na wszystko, co istnieje - otwiera go w sposób szczególny na drugiego człowieka, otwiera go na życie „w komunii”. Otwiera mężczyznę i kobietę w stronę małżeństwa i rodziny. Rodzina bierze początek w miłości mężczyzny i kobiety, bierze początek także w Bożej tajemnicy. Odpowiada on najbardziej intymnej istocie obojga: mężczyzny i kobiety. Odpowiada ich autentycznej osobowej godności ${ }^{13}$. W adhortacji Familiaris consortio Jan Paweł II pisał, że w zamyśle Boga Stworzyciela i Odkupiciela rodzina odkrywa nie tylko swoją „tożsamość”, to czym ,jest”, ale również swoje „posłannictwo, to, co może i powinna „czynić”. Odkrywa zadania, które z powołania Bożego ma wypełniać $\mathrm{w}$ historii, a które wypływają z samej jej istoty i ukazują jej dynamiczny i egzystencjalny rozwój. Każda rodzina odkrywa i znajduje w sobie samej niedające się stłumić wezwanie, które jednocześnie określa jej godność i odpowiedzialność: rodzino, „stań się” tym, czym ,jesteś”! Sięganie do „początku” stwórczego aktu Boga jest koniecznością dla rodziny, jeżeli pragnie ona poznać i urzeczywistnić siebie wedle prawdy, która mówi, że wedle zamysłu Bożego jest ona „wspólnotą życia i miłości” (KDK 48). Stąd wypływa istota i zadania rodziny, które są określone przez miłość, i dlatego rodzina otrzymuje misję strzeżenia, objawiania i przekazywania miłości, będącej żywym odbiciem i rzeczywistym udzielaniem się miłości Bożej ludzkości oraz miłości Chrystusa Pana Kościołowi, Jego oblubienicy ${ }^{14}$. A miłość Boża rodzi życie i chroni życie.

Relacja miłości jest jednym z fundamentalnych elementów mówiących o tożsamości małżeństwa i rodziny. Już papież Paweł VI nauczał, że miłość małżeńska najlepiej objawia nam swą prawdziwą naturę i godność dopiero wtedy, gdy rozważymy, że początek swój czerpie ona - jakby z najwyższego źródła - z Boga, który jest Miłością i Ojcem. Małżeństwo bowiem nie jest wyrokiem jakiegoś przypadku lub owocem ewolucji ślepych sił przyrody. Jest mądrze i opatrznościowo ustanowione przez Stwórcę, aby urzeczywistniać w ludziach swój plan miłości. Dlatego małżonkowie poprzez wzajemne oddanie się sobie, im tylko właściwe i wyłączne, dążą do takiej wspólnoty osób, aby doskonaląc się w niej wzajemnie, współpracować równocześnie z Bogiem w wydawaniu na świat i wychowywaniu nowych ludzi. Dla ochrzczonych zaś małżeństwo nabiera godności sakramentalnego znaku łaski, ponieważ wyraża związek Chrystusa z Kościołem ${ }^{15}$. Małżeństwo jako

13 Jan Paweł II, List do Rodzin (02.02.1994), n. 8.

14 Idem, Familiaris consortio (22.11.1981), n. 17; por. Relatio Synodi III Nadzwyczajnego Zgromadzenia Ogólnego Synodu Biskupów, n. 17.

$15 \quad$ Paweł VI, Humanae vitae (25.07.1968). n. 8. 
wspólnota życia i miłości, jest więc naturalną instytucją ustanowioną przez Boga i wyłącznie jemu powierzona jest misja przekazywania życia. Jako sakrament może stać się okazją do świadczenia przez małżonków o Ewangelii miłości, życia i rodziny ${ }^{16}$. Małżeństwo sakramentalne uczestnicząc w ostatecznym przymierzu Chrystusa z Kościołem zakłada, iż małżonkowie chrześcijańscy odpowiadają na powołanie Boże i podejmują misję bycia znakiem miłości Boga dla wszystkich członków rodziny ludzkiej. Stają się współpracownikami Boga w obdarowywaniu życiem i miłością ${ }^{17}$. To miłość sprawia, że człowiek urzeczywistnia siebie przez bezinteresowny dar z siebie. Miłość bowiem jest dawaniem i przyjmowaniem daru. Nie można jej kupować ani sprzedawać. Można się nią tylko wzajemnie obdarowywać. Dar osoby z istoty swojej jest trwały i nieodwołalny. Nierozerwalność małżeństwa wynika nade wszystko z samej istoty tego daru: dar osoby dla osoby. W tym wzajemnym darze wyraża się oblubieńczy charakter miłości ${ }^{18}$. Bóg chciał od samego początku, by przymierze małżeńskie, małżeństwo stworzenia, było stałym znakiem jedności Chrystusa z Kościołem, a tym samym, rzeczywistym sakramentem Nowego Przymierza. Sakramentalność małżeństwa nie jest więc czymś dodanym lub zewnętrznym wobec natury małżeństwa, lecz jest to to samo nierozerwalne małżeństwo wyniesione do rangi sakramentu przez zbawcze dzieło Chrystusa. Łaska sakramentu małżeństwa nadaje dynamizmu istocie małżeństwa ${ }^{19} \mathrm{i}$ uzdalnia małżonków do realizacji podjętych zobowiązań małżeńskich, do świadczenia o małżeńskiej miłości. Łaska sakramentu małżeństwa uzdalnia małżonków do urzeczywistnia w codzienności życia, miłości na wzór miłości Chrystusa do Kościoła, gdyż „nie jest możliwe, by człowiek własnymi tylko siłami urzeczywistnił doskonały dar z siebie. Staje się do tego zdolny mocą łaski Ducha Świętego. W rzeczywistości to Chrystus objawia pierwotną prawdę małżeństwa. Wyzwalając człowieka z zatwardziałości serca, Chrystus czyni go zdolnym do urzeczywistnienia pełnej prawdy małżeństwa"20, mocą łaski, którą obdarza małżonków w sakramencie małżeństwa.

Por. Papieska Rada ds. Rodziny, Przygotowanie do sakramentu matżeństwa, n. 10; Karta Praw Rodziny (22.10.1983), Wstęp C.

17 Papieska Rada ds. Rodziny, Przygotowanie do sakramentu matżeństwa, n. 16. Por. Jan Paweł II, List do Rodzin, n. 11.

Por. Papieska Rada ds. Rodziny, Rodzina matżenstwo i „wolne związk”, n. 35.

20 Papieska Rada ds. Rodziny, Vademecum dla spowiedników (12.02.1997), [w:] M. Brzeziński (red.), W trosce o dobro matżeństwa i rodziny. t. 1, Dokumenty Papieskiej Rady ds. Rodziny, Lublin 2010, s. 213-214. 
Wspólnota rodzinna powstaje z zawarcia przymierza między małżonkami. Małżeństwo powstaje z przymierza miłości małżeńskiej, głębokim i uzupełniającym się związku mężczyzny i kobiety. Opiera się na więzi małżeństwa zawartego dobrowolnie i publicznie, jest instytucją naturalną, niepowtarzalną i pierwotną w stosunku do innych społeczności ${ }^{21}$. Rodzina jest wspólnotą zbudowaną na miłości i przez miłość ożywianą. Rodzina z przymierza miłości, które jest nierozerwalne, i które tworzy z małżonków komunię osób czerpie siłę do życia miłością i bycia współpracownikami Boga w przekazywaniu życia ${ }^{22}$ tworząc wspólnotę, sanktuarium życia i miłości, domowy Kościół.

\section{Małżeństwo wspólnotą miłości mężczyzny i kobiety}

Człowiek od momentu stworzenia jest powołany do miłości a doświadczając jej w życiu mówi o swoim spełnieniu i szczęściu. Już na początku swego pontyfikatu Jan Paweł II nauczał, że

człowiek nie może żyć bez miłości. Człowiek pozostaje dla siebie istotą niezrozumiałą, jego życie jest pozbawione sensu, jeśli nie objawi mu się Miłość, jeśli nie spotka się z Miłością, jeśli jej nie dotknie i nie uczyni w jakiś sposób swoją, jeśli nie znajdzie w niej żywego uczestnictwa ${ }^{23}$.

Człowiek poszukuje miłości i prawdy o niej w spotkaniu z Bogiem, by z kolei urzeczywistnić tę miłość w spotkaniu z drugim człowiekiem, poszukuje jej zwłaszcza w powołaniu do małżeństwa. Dla człowieka „miłość staje się swoistym kryterium oceny decydującym ostatecznie o wartości lub bezwartościowości jego życia" ${ }^{24}$. Jednakże rzeczywistość otaczającego świata, wpływy zewnętrzne, przemiany społeczne sprawiają, że prawda o miłości objawiona przez Boga w Jezusie Chrystusie może ulec zaciemnieniu i jej wartościowaniu. Mówił o tym Paweł VI, podkreślając, że w dzisiejszym społeczeństwie dają się zauważyć pewne zmiany także w ocenie wartości miłości małżeńskiej oraz znaczenia stosunków małżeńskich dla tej miłości ${ }^{25}$. Z jeszcze większą uwagą i zatroskaniem w rozumieniu znaczenia miłości w dzisiejszym świecie pochyla się Benedykt XVI w encyklice Deus Caritas Est. Podkreśla on,

$21 \quad$ Por. Papieska Rada ds. Rodziny, Rodzina matżeństwo i „wolne zwiazki”, n. 9; Karta Praw Rodziny, Wstęp B.

22 Por. ibidem, n. 12.

23 Jan Paweł II, Redemprtor hominis (04.03.1979), n. 10; por. idem, Familiaris consortio, n. 18.

$24 \quad$ Benedykt XVI, Deus Caritas Est (25.12.2005), n. 15. 
że termin „miłość” stał się dziś jednym ze słów najczęściej używanych i także nadużywanych, którym nadajemy znaczenia zupełnie różne. Jednak w wielości znaczeń, jakie nadaje świat miłości, to miłość między mężczyzną i kobietą, w której ciało i dusza uczestniczą w sposób nierozerwalny, i w której przed istotą ludzką otwiera się obietnica szczęścia, pozornie nie do odparcia, wyłania się jako wzór miłości w całym tego słowa znaczeniu, w porównaniu z którym na pierwszy rzut oka każdy inny rodzaj miłości blednie ${ }^{26}$. Małżeńska miłość między mężczyzną i kobietą, między mężem a żoną wyraża doświadczenie miłości, która staje się odkryciem drugiego człowieka, staje się troską i służbą współmałżonkowi. Taka miłość nie szuka już samej siebie, zanurzenia w upojeniu szczęściem, lecz poszukuje dobra osoby ukochanej: staje się wyrzeczeniem, jest gotowa do poświęceń. Miłość małżeńska poszukuje w swoim rozwoju definitywności i to w podwójnym znaczeniu: w sensie wyłączności - tylko ta jedyna osoba - i w sensie „na zawsze”. Miłość obejmuje całość egzystencji w każdym jej wymiarze, także w wymiarze czasu. Nie mogłoby być inaczej, ponieważ jej obietnica ma na celu definitywność: miłość dąży do wieczności. Taka miłość jest również „ekstazą”. Ekstazą nie w sensie chwili upojenia, lecz ekstazą jako droga, trwałe wychodzenie z ,ja" zamkniętego w samym sobie w kierunku wyzwolenia ,ja” w darze z siebie i właśnie tak w kierunku ponownego znalezienia siebie, a nawet w kierunku odkrycia Boga: „Kto będzie się starał zachować swoje życie, straci je; a kto je straci, zachowa je" (Łk 17, 33) - mówi Jezus ${ }^{27}$. Sens tej miłości zawiera się w słowach przysięgi małżeńskiej, kiedy mężczyzna i kobieta ślubują sobie nawzajem miłość, wzajemne ofiarowanie i przyjęcie miłości przez małżonków, a z kolei obdarowanie nią dzieci. Z treści przysięgi płynie zobowiązanie do realizacji misji obdarowywania miłością, poznawania prawdy o miłości i głoszenia miłości. Miłość pomiędzy mężczyzną i kobietą w małżeństwie, i w konsekwencji miłość pomiędzy członkami tej samej rodziny - pomiędzy rodzicami i dziećmi, pomiędzy braćmi i siostrami, pomiędzy krewnymi i domownikami - jest ożywiana i podtrzymywana przez wewnętrzny, nieustający dynamizm, prowadzący rodzinę do coraz głębszej i mocniejszej komunii, która jest fundamentem i zasadą wspólnoty małżeńskiej i rodzinnejej.

Przyjmując siebie nawzajem i za łaską Chrystusa, nowożeńcy przyrzekają sobie całkowity dar, wierność i otwartość na życie. Uznają oni za elementy konstytutywne małżeństwa dary, jakimi obdarza ich Bóg,

$26 \quad$ Benedykt XVI, Deus Caritas Est, n. 2.

27 Ibidem, n. 6 . 
podejmując na serio swoje wzajemne zobowiązanie, w Jego imię i wobec Kościoła. Otóż w wierze możliwe jest podjęcie dóbr małżeństwa jako zobowiązania łatwiejszego do uniesienia dzięki pomocy łaski sakramentu. Bóg uświęca miłość małżonków i umacnia jej nierozerwalność, dając im pomoc, aby żyć wiernością, wzajemnym zintegrowaniem i otwartością na życie. Dlatego spojrzenie Kościoła kieruje się na małżonków, jako na serce całej rodziny, która także kieruje swoje spojrzenie ku Jezusowi ${ }^{29}$.

Należy podkreślić fakt, iż w odkrywaniu prawdy o miłości, często wiele osób błędnie o niej myśli, że miłość jest tylko uczuciem. Uczucia przychodzą i odchodzą. Uczucie może być cudowną iskrą rozniecającą, lecz nie jest pełnią miłości. Należy do dojrzałości miłości to, że angażuje wszystkie potencjalne możliwości człowieka zaangażowania woli i intelektu ${ }^{30}$ tak, by stała się postawą, a nie przemijającym uczuciem. Postawą, która wyraża troskę o osobę, którą się kocha, i którą Bóg powierzył naszej odpowiedzialności ${ }^{31}$. W rodzinie, każda z osób jest powierzona innym i jest odpowiedzialna za pozostałe, za posługę miłości względem pozostałych członków rodziny.

Rodzina, założona i ożywiana przez miłość, jest wspólnotą osób: mężczyzny i kobiety jako małżonków, rodziców, dzieci i krewnych. Pierwszym jej zadaniem jest wierne przeżywanie rzeczywistości komunii w ciągłym działaniu na rzecz rozwijania prawdziwej wspólnoty osób. Wewnętrzną zasadą, trwałą mocą i celem ostatecznym tego zadania jest miłość: tak jak bez miłości rodzina nie jest wspólnotą osób, tak samo bez miłości nie może ona żyć, wzrastać i doskonalić się jako wspólnota osób ${ }^{32}$.

Panujący w rodzinie duch miłości kieruje członkami rodziny, ich postawami i zachowaniami. W tym duchu człowiek kształtuje swoje człowieczeństwo, uczy się postaw prospołecznych wynikających z miłości wobec innych, koryguje i docenia dobre rzeczy ${ }^{33}$.

W dzisiejszym, szybko zmieniającym się świecie, co podkreślał Jan Paweł II rodzina, tak jak zawsze, poszukuje „pięknej miłości”. Miłość, piękna jest prawdziwa i tworzy dobro osoby i wspólnot. Miłość, która nie jest piękna, która jest tylko wzajemnym „używaniem” siebie przez mężczyznę i kobietę, czyni człowieka niewolnikiem własnych słabości i nie czyni go szczęśliwym ${ }^{34}$, a człowiek poprzez doświadczenie miłości

29 Relatio Synodi III Nadzwyczajnego Zgromadzenia Ogólnego Synodu Biskupów, n. 21.

30 Benedykt XVI, Deus Caritas Est, n. 17.

31 Jan Paweł II, Evangelium vitae (25.03.1995), n. 87.

32 Idem, Familiaris consortio, n. 18.

$33 \quad$ Franciszek, Evangelii gaudium, n. 139. 
i obdarowywania miłością pragnie obdarzać szczęściem i sam być szczęśliwym. Dlatego,

aby miłość była piękna, musi być darem Bożym, musi być zaszczepiona w sercach ludzkich przez Ducha Świętego i stale w nich podtrzymywana (por. Rz 5, 5). Aby była „piękną miłością”, czyli darem osoby dla osoby, musi pochodzić od Tego, który sam jest Darem i Źródłem wszelkich darów ${ }^{35}$.

Piękna miłość, która zakorzeniona jest w miłości Boga i czerpie z niej jako źródła, uświęca małżonków i umacnia ich nierozerwalność, dając im pomoc, aby żyć wiernością, wzajemnym zintegrowaniem i otwartością na życie ${ }^{36}$. Budowanie i rozwijanie „pięknej miłości”, jest „procesem, który pozostaje w ciągłym rozwoju: miłość nigdy nie jest „skończona” i spełniona; miłość zmienia się wraz z biegiem życia, dojrzewa i właśnie dlatego pozostaje wierna samej sobie ${ }^{37}$.

Rodzina jest centrum i sercem cywilizacji miłości. Nie ma prawdziwej miłości bez świadomości, że Bóg przede wszystkim „,jest Miłością” - oraz, że człowiek jest tym jedynym stworzeniem, którego Bóg powołał do istnienia „dla niego samego”. Ten zaś stworzony na obraz i podobieństwo Boga człowiek nie może się w pełni „urzeczywistnić” inaczej jak tylko przez bezinteresowny dar z siebie samego. Bez takiego pojęcia człowieka, osoby oraz „komunii osób” w rodzinie nie może być cywilizacji miłości ${ }^{38}$.

\section{Życie misją rodziny}

„Stwórca wszechrzeczy jest Bogiem miłości i życia. Pragnie, aby człowiek miał życie i aby miał je w obfitości, jak mówi Chrystus (J 10, 10) - może przede wszystkim - dzięki rodzinie" ${ }^{39}$. Dar życia według słów Jana Pawła II został złożony przez Boga w ręce człowieka, i tym samym został on zaproszony do współpracy ze Stwórcą w dziele współtworzenia świata przez obdarowywanie życiem. Przyjęcie tego zadania i „otwarcie na życie jest istotnym wymogiem miłości małżeńskiej” ${ }^{40}$,

35 Ibidem, n. 20.

36 Relatio Synodi III Nadzwyczajnego Zgromadzenia Ogólnego Synodu Biskupów, n. 21.

37 Benedykt XVI, Deus Caritas Est, n. 17.

38 Jan Paweł II, List do Rodzin, n. 12.

39 Ibidem, n. 15.

40 Relatio Synodi III Nadzwyczajnego Zgromadzenia Ogólnego Synodu Biskupów, n. 57. 
a służba życiu stanowi też o tożsamości rodziny jako wspólnoty miłości. Jasne jest, że zgodnie z wolą Stwórcy odpowiedzialność za przekazywanie życia spoczywa na rodzinie. Odpowiedzialność ta wypływa z samej natury rodziny - jako wspólnoty życia i miłości, opartej na małżeństwie - i z jej misji „strzeżenia, objawiania i przekazywania miłości” (FC 15). Mowa tu o miłości Boga, którego współpracownikami i w pewnym sensie rzecznikami stają się rodzice, gdy przekazują życie i wychowują je zgodnie z Jego ojcowskim zamysłem (por. KDK $50)^{41}$. Wypełnianie powołania do przekazywania życia i służby życiu

wyraża się w różnych formach służenia życiu. Wśród nich najbardziej bezpośrednie, właściwe małżeństwu i zarazem takie, w których nic małżeństwa nie może zastąpić, to rodzenie i wychowanie. W istocie każdy akt prawdziwej miłości wobec człowieka potwierdza i doskonali duchową płodność rodziny, będąc aktem posłuszeństwa wobec głębokiego, wewnętrznego dynamizmu miłości, rozumianej jako oddawanie siebie innym ${ }^{42}$.

Rodzice powinni uważać swoją misję i powołanie do przekazywania życia jako zaszczyt i odpowiedzialność, ponieważ stają się współpracownikami Boga w powoływaniu do życia nowej osoby ludzkiej, która nosi w sobie obraz i podobieństwo Boga i jest zaproszona do uczestnictwa w życiu Bożym. Bycie współpracownikami Boga stanowi o wielkości małżonków gotowych do współpracy ze Stwórcą ${ }^{43}$. Służba życiu staje się podstawowym zadaniem rodziny, urzeczywistnianiem w ciągu dziejów pierwotnego błogosławieństwa Stwórcy: przekazywania - poprzez rodzenie obrazu Bożego z człowieka na człowieka. Płodna miłość małżeńska jest żywym świadectwem, pełnym wzajemnego oddawania się małżonków, oraz otwartością na współdziałanie z miłością Stwórcy, w przekazywaniu życia i służbie życiu ${ }^{44}$.

Służba życiu w małżeństwie i rodzinie oraz

płodność miłości małżeńskiej nie zacieśnia się jednakże tylko do fizycznego rodzenia dzieci, choćby nawet była pojmowana w swym specyficznie ludzkim wymiarze: poszerza się i ubogaca wszelkimi owocami życia moralnego, duchowego i nadprzyrodzonego, jakie ojciec i matka $\mathrm{z}$ racji swego powołania winni przekazać $\mathrm{w}$ darze dzieciom, a poprzez dzieci, Kościołowi i światu ${ }^{45}$.

\footnotetext{
$41 \quad$ Jan Paweł II, Evangelium vitae, n. 92.

42 Idem, Familiaris consortio, n. 41.

43 Por. Papieska Rada ds. Rodziny, Vademecum dla spowiedników, s. 215-216.

44 Por. Jan Paweł II, Familiaris consortio, n. 28.

Ibidem.
} 
Człowiek jest powołany do pełni życia, która przekracza znacznie wymiary jego ziemskiego bytowania, ponieważ polega na uczestnictwie w życiu Boga. Wzniosłość tego nadprzyrodzonego powołania ukazuje wielkość i ogromną wartość ludzkiego życia także w jego fazie doczesnej ${ }^{46}$. Służba życiu w rodzinie dotyczy więc aspektu przekazywania życia w sensie biologicznym, ale musi uwzględniać całego człowieka i całe jego powołanie, obejmujące nie tylko porządek naturalny i doczesny, ale również nadprzyrodzony i wieczny ${ }^{47}$. I jeśli życie w czasie jest podstawowym warunkiem, początkowym etapem i integralną częścią całego i niepodzielnego procesu ludzkiej egzystencji, tak proces ten zostaje opromieniony obietnicą i odnowiony przez dar życia Bożego, które urzeczywistni się w pełni w wieczności (1 J 3, 1-2). Równocześnie to nadprzyrodzone powołanie uwydatnia względność ziemskiego życia człowieka. Życie doczesne nie jest rzeczywistością „ostateczną”, ale Teologia rodziny „przedostateczną”; jest rzeczywistością świętą, która zostaje człowiekowi powierzona, aby jej strzegł z poczuciem odpowiedzialności i doskonalił ją przez miłość i dar z siebie ofiarowany Bogu i braciom ${ }^{48}$. Choć

ludzkie rodzicielstwo jest biologicznie podobne do prokreacji innych istot żyjących w przyrodzie, to istotowo jest „podobne” - ono jedno do Boga samego. Takie właśnie rodzicielstwo stoi u podstaw rodziny jako ludzkiej wspólnoty życia: jako wspólnoty osób zjednoczonych w miłości ${ }^{49}$.

Logika bezinteresownego daru wkracza w ich życie, kiedy mężczyzna i kobieta w małżeństwie wzajemnie się sobie oddają i wzajemnie przyjmują jako „,jedno ciało” i jedność dwojga. Komunia osób zbudowana na tej logice daru staje się komunią rodzicielską. Małżonkowie bezinteresownie się sobie oddając dają życie własnemu dziecku ${ }^{50}$.

Ponieważ życie ludzkie, ma swój wymiar nie tylko doczesny, ale i wieczny jest cennym darem Bożym, jest święte i nienaruszalne, co oznacza w szczególności, że absolutnie niedopuszczalna jest jakakolwiek ingerencja prowadząca do przerwania jego istnienia. Życia ludzkiego nie tylko nie wolno zabijać, ale trzeba je chronić, otaczając je troskliwą opieką, zwłaszcza w sanktuarium życia i miłości, którym jest rodzina. Życie ludzkie znajduje swój sens, gdy może poczuć, że jest

\footnotetext{
$46 \quad$ Jan Paweł II, Evangelium vitae, n. 2.

$47 \quad$ Por. Paweł VI, Humanae vitae, n. 7.

48 Jan Paweł II, Evangelium vitae, n. 2.

49 Idem, List do Rodzin, n. 6.

$50 \quad$ Por. ibidem, n. 11.
} 
kochane i może kochać51. Dlatego obrona i promocja życia ludzkiego powinna mieć charakter posługi miłości, i powinna rodzić się także z wiary, „która działa przez miłość” $(\mathrm{Ga} 5,6)^{52}$. Dlatego bronić życia i umacniać je, czcić je i kochać, to zadanie, które Bóg powierza każdemu człowiekowi. Jednakże to panowanie, przekazane przez Stwórcę człowiekowi, nie oznacza władzy absolutnej nad ludzkim życiem ${ }^{53}$, lecz władzą zgodną z prawami i normami, które Bóg Stwórca człowiekowi pozostawił. Każdy

nowy człowiek od chwili poczęcia, a potem urodzenia, przeznaczony jest do tego, ażeby w pełni się wyraziło jego człowieczeństwo, ażeby się ono „urzeczywistniło”. Odnosi się to do wszystkich, również do chronicznie chorych i niedorozwiniętych. „Być człowiekiem” - to podstawowe powołanie człowieka: „być człowiekiem” na miarę daru, jaki otrzymał. Na miarę tego „talentu”, którym jest samo człowieczeństwo, a z kolei dopiero na miarę wszystkich talentów, jakimi został obdarzony. W tym znaczeniu Bóg chce każdego człowieka „dla niego samego" ${ }^{54}$.

I dlatego wspólnota rodzinna musi stać na straży ludzkiego życia i z miłością podejmować wszelką posługę wobec każdego życia, aby mogło urzeczywistnić się jego człowieczeństwo. Posługa miłości i służba życiu powinna obejmować wszystko i wszystkich, ponieważ życie ludzkie jest święte i nienaruszalne w każdej swojej fazie i kondycji; jest ono dobrem niepodzielnym. Trzeba zatem „zatroszczyć się” o całe życie i o życie wszystkich ${ }^{55}$, pokonując wszelkie trudności, począwszy od tych związanych z przyjęciem rodzącego się życia, do tych związanych z obecnością osób starszych, chorych, niepełnosprawnych, jako obciążenia ${ }^{56}$. Szczególne znaczenie w życiu rodzinnym i w służbie życiu w rodzinie odgrywa czwarte przykazanie „czcij ojca twego i matkę twoją". Dotyczy ono bowiem wewnętrznej spoistości i solidarności w rodzinie. Słowo „czcij” wyraża w inny sposób czym jest rodzina. Rodzina jest wspólnotą szczególnie intensywnych odniesień: pomiędzy małżonkami, pomiędzy rodzicami a dziećmi oraz między pokoleniami ${ }^{57}$.

\footnotetext{
$51 \quad$ Jan Paweł II, Evangelium vitae, n. 81.

52 Ibidem, n. 87.

53 Por. Jan Paweł II, Evangelium vitae, n. 42.

54 Idem, List do Rodzin, n. 9.

$55 \quad$ Idem, Evangelium vitae, n. 87.

Relatio Synodi III Nadzwyczajnego Zgromadzenia Ogólnego Synodu Biskupów, n. 6 .

57 Por. Jan Paweł II, List do Rodzin, n. 15.
} 
Czwarte przykazanie jest szczególnie blisko związane z przykazaniem miłości, pomiędzy „czcij” a „miłuj” zachodzi bardzo bliski związek znaczeniowy. U swych podstaw, cześć odpowiada cnocie sprawiedliwości. W istocie rzeczy nie można jednak pomyśleć Czci bez miłości i to zarazem Boga i bliźniego. Chodzi wszakże o „bliźnich” w znaczeniu najbliższym i najściślejszym, a więc o rodziców i dzieci ${ }^{58}$.

\section{W życiu rodzinnym}

przykazanie „czcij ojca i matkę” pośrednio mówi rodzicom: czcijcie wasze dzieci, synów i córki tak, jak one na to zasługują. Zasługują zaś dlatego, że są, oraz dlatego, że są tym, kim są - i to od pierwszej chwili poczęcia. Przykazanie to pozostaje nie tylko wyrazem wewnętrznej więzi rodziny, ale ukazuje również zasadę ich wewnętrznej spójni ${ }^{59}$.

Przykazanie to wskazuje więc na wzajemną cześć: dzieci do rodziców, ale i rodziców do dzieci.

Wypada zauważyć, że wszystkie „prawa człowieka” mogą być kruche i nieskuteczne, jeżeli u podstaw zabraknie „czcij”. Jeżeli zabraknie „czci”, inaczej mówiąc: afirmacji człowieka dlatego, że jest człowiekiem, że jest „tym” człowiekiem, wówczas same prawa nie wystarczą ${ }^{60}$.

Wzajemna cześć i miłość obejmuje wszystkich w rodzinie. Rodzina ma być tym miejscem, gdzie życie, które domaga się większej życzliwości, miłości i opieki, jest uznawane za bezużyteczne lub traktowane jako nieznośny ciężar, a w konsekwencji odrzucane na różne sposoby przez społeczeństwo, to ma swoje należne miejsce w rodzinie. Człowiek, który swoją chorobą, niepełnosprawnością lub samą swoją obecnością zagraża dobrobytowi lub życiowym przyzwyczajeniom osób bardziej uprzywilejowanych, bywa postrzegany jako wróg, przed którym należy się bronić albo, którego należy wyeliminować ${ }^{61}$, w rodzinie ma on znajdować swoje miejsce, gdzie będzie otoczony miłością, będzie chciany i oczekiwany. Jeśli powodem, dla którego społeczeństwo odrzuca ludzkie życie jest brak Boga w sercach ludzi, Boga, którego miłość jedynie jest silniejsza od wszelkich możliwych obaw świata, i tylko ona może je przezwyciężyć, to rodzina żyje tą miłością i ogarnia nią każdego swego członka ${ }^{62}$. Aby rodzina mogła wypełnić swoje powołanie jako „sanktuarium życia” i komórka społeczeństwa, które miłuje i przyjmuje życie, należy koniecznie i pilnie zapewnić jej

\footnotetext{
58 Ibidem.

$59 \quad$ Ibidem.

60 Jan Paweł II, List do Rodzin, n. 15.

61 Idem, Evangelium vitae, n. 12.

62 Por. idem, Familiaris consortio, n. 30.
} 
pomoc i oparcie. Społeczeństwo i państwo powinny udzielić wszelkiej i niezbędnej pomocy, także ekonomicznej, aby rodziny mogły rozwiązywać swoje problemy w sposób bardziej ludzki. Ze swej strony Kościół winien niestrudzenie rozwijać duszpasterstwo rodzin zdolne pobudzić każdą rodzinę do odkrycia i przeżywania z radością i odwagą misji wyznaczonej jej przez Ewangelię życia ${ }^{63}$.

\section{Rodzina głosi Ewangelię miłości i życia}

Rozpoczynając Rok Wiary w Kościele, papież Benedykt XVI pisał, iż

miłość Chrystusa wypełnia nasze serca i pobudza nas do ewangelizacji. Dzisiaj, tak jak wówczas, wysyła On nas na drogi świata, aby głosić Jego Ewangelię wszystkim narodom ziemi (Mt 28, 19). Poprzez swą miłość Jezus Chrystus przyciąga do Siebie ludzi z każdego pokolenia: w każdym czasie zwołuje on Kościół, powierzając mu głoszenie Ewangelii, z nakazem, który zawsze jest nowy. $Z$ tego względu także dziś potrzeba bardziej przekonującego zaangażowania kościelnego na rzecz nowej ewangelizacji, aby na nowo odkryć radość w wierze i odnaleźć entuzjazm w przekazywaniu wiary. Zaangażowanie misyjne wierzących, które nigdy nie może słabnąć, czerpie moc i siłę w codziennym odkrywaniu Jego miłości. Wiara bowiem rośnie, gdy przeżywana jest jako doświadczenie otrzymanej miłości i kiedy jest przekazywana jako doświadczenie łaski i radości. Sprawia ona, że życie wiernych wydaje owoce, ponieważ poszerza serca w nadziei i pozwala na dawanie twórczego świadectwa: otwiera w istocie serca i umysły tych, którzy słuchają, na zaproszenie Pana, aby przylgnęli do Jego słowa, by stali się Jego uczniami ${ }^{64}$.

Wiara bez miłości nie przynosi owocu, a miłość bez wiary byłaby uczuciem nieustannie na łasce i niełasce wątpliwości. Wiara i miłość potrzebują siebie nawzajem, tak że jedna pozwala drugiej, by mogła się zrealizować. Niemało chrześcijan rzeczywiście poświęca swoje życie z miłością samotnym, znajdującym się na marginesie lub wykluczonym, jako tym, do których trzeba pójść jako pierwszych i najważniejszych, których trzeba wesprzeć, ponieważ właśnie w nich odzwierciedla się oblicze samego Chrystusa ${ }^{65}$.

„Wiara potrzebuje bowiem środowiska, w którym można o niej świadczyć i ją przekazywać, a winno być ono odpowiednie i proporcjonalne

\footnotetext{
$63 \quad$ Jan Paweł II, Evangelium vitae, n. 94.

64 Benedykt XVI, Porta fidei (11.10.2011), n. 7.

65 Ibidem, n. 14.
} 
do tego, co się komunikuje"66, a pierwszym środowiskiem, w którym wiara jest przekazywana jest rodzina - domowy Kościół. Rodzina zbudowana na fundamencie trwałej i nierozerwalnej miłości mężczyzny i kobiety, będącej znakiem i obecnością miłości Bożej, z uznania i akceptacji dobra odmienności seksualnej, dzięki czemu małżonkowie mogą stać się jednym ciałem ( $R d z 2,24)$ i są zdolni zrodzić nowe życie, co jest przejawem dobroci, miłości i mądrości Stwórcy. Opierając się na tej miłości, mężczyzna i kobieta mogą przyrzec sobie wzajemną miłość gestem angażującym całe życie i przypominającym bardzo wiele cech wiary. Przyrzeczenie miłości na zawsze staje się możliwe, gdy odkrywamy większy od naszych projektów plan, który nas wspiera i pozwala nam ofiarować ukochanej osobie całą przyszłość. Wiara pomaga też pojąć w całej głębi i bogactwie zrodzenie dzieci sprawiając, że uznajemy w nim stwórczą miłość, która daje nam i powierza Teologia rodziny tajemnicę nowej osoby ${ }^{67}$. Dzielenie się wiarą w domach i rodzinach, prowadzi do odczucia przez wszystkich w rodzinie silnego odczucia potrzeby lepszego zrozumienia i przekazywania wiary ${ }^{68}$.

W rodzinie wiara towarzyszy wszystkim okresom życia, poczynając od dzieciństwa: dzieci uczą się pokładać ufność w miłości swoich rodziców. Dlatego jest ważne, aby rodzice dbali o wspólne praktykowanie wiary w rodzinie, towarzyszyli dojrzewaniu wiary dzieci. Zwłaszcza młodzież przeżywająca tak skomplikowany, bogaty i ważny dla wiary okres życia, musi czuć bliskość i troskę rodziny, aby mogła okazywać radość wiary, podejmować zobowiązanie do życia wiarą w sposób coraz trwalszy i bardziej wielkoduszny. Spotkanie z Chrystusem, pozwolenie, by nas ujęła i prowadziła Jego miłość, poszerza horyzont życia, daje mu mocną nadzieję, która nie zawodzi. Wiara nie jest ucieczką dla ludzi mało odważnych, lecz poszerzaniem przestrzeni życia. Pozwala ona odkryć wielkie wezwanie, powołanie do miłości, i daje pewność, że ta miłość jest godna zaufania, że warto się jej powierzyć, ponieważ jej fundamentem jest wierność Boga, mocniejsza od wszystkich naszych słabości ${ }^{69}$.

Jeśli ktoś rzeczywiście doświadczył miłości Boga, który go zbawia, nie potrzebuje wiele czasu, by zacząć Go głosić i nie może oczekiwać, aby udzielono mu wielu lekcji lub długich pouczeń. Każdy chrześcijanin jest misjonarzem w takiej mierze, w jakiej spotkał się z miłością Boga w Chrystusie Jezusie ${ }^{70}$.

Franciszek, Lumen fidei, (29.06.2013), n. 40.

67 Ibidem, n. 52.

Por. Benedykt XVI, Porta fidei, n. 8.

Franciszek, Lumen fidei, n. 53.

Idem, Evangelii gaudium, n. 120.
} 
Spotkanie z Chrystusem prowadzi do dzielenia się tym z innymi, do dzielenia się doświadczeniem miłości Boga w tym spotkaniu. I to jest już głoszeniem Ewangelii. Głoszenie to powinno wypływać z doświadczenia, że Ewangelia rodziny jest odpowiedzią na najgłębsze pragnienia człowieka: jego godności i pełnej realizacji we wzajemności, w jedności i płodności. Nie chodzi tylko o przedstawienie jakiś normatywów, ale zaproponowanie wartości, odpowiadając na ich zapotrzebowanie, które stwierdzamy dziś także w krajach najbardziej zlaicyzowanych ${ }^{71}$. Głoszenie Ewangelii życia nie jest jedynie refleksją, choćby oryginalną i głęboką, nad ludzkim życiem; nie jest też wyłącznie przykazaniem, które ma uwrażliwiać sumienia i wywołać głębokie przemiany społeczne; tym bardziej też nie jest złudną obietnicą lepszej przyszłości. Ewangelia życia jest rzeczywistością konkretną i osobową, gdyż polega na głoszeniu osoby samego Jezusa. Tak więc słowa, czyny i sama osoba Jezusa dają człowiekowi możliwość „,poznania” pełnej prawdy o wartości życia ludzkiego; z tego „źródła” czerpie on zwłaszcza zdolność doskonałego „czynienia” tej prawdy (por. J 3, 21), to znaczy przyjęcia i pełnej realizacji obowiązku miłowania ludzkiego życia i służenia mu, bronienia go i wspomagania $^{72}$. Ponadto rodzina wysławia Ewangelię życia przez codzienną modlitwę osobistą i rodzinną: chwali w niej Boga i dziękuje Mu za dar życia, prosi o światło i moc, aby stawiać czoło trudnościom i cierpieniom, nigdy nie tracąc nadziei. Jednakże sposobem wysławiania, które nadaje sens wszelkim innym formom modlitwy i kultu jest ten, który się wyraża w codziennym życiu rodziny, gdy jego treść stanowi miłość i ofiara. W ten sposób wysławianie przekształca się w służbę Ewangelii życia, której wyrazem jest solidarność, doświadczana wewnątrz i na zewnątrz rodziny jako czujna i serdeczna troska o człowieka i jego życie. Szczególnie wymownym znakiem solidarności między rodzinami jest adopcja lub wzięcie pod opiekę dzieci porzuconych przez rodziców czy też żyjących w trudnych warunkach. Służba Ewangelii życia polega również na tym, że rodziny, głównie przez zrzeszanie się w odpowiednich organizacjach, starają się tak oddziaływać na prawodawstwo i na instytucje państwowe, aby w żaden sposób nie naruszały one prawa do życia od poczęcia do naturalnej śmierci, ale chroniły je i umacniały ${ }^{73}$.

Głoszenie Ewangelii życia to troska, by prawo Boże było przestrzegane, ale także dzielenie się przez małżonków swoimi doświadczeniami, z innymi małżonkami, jako swoistą formą apostolatu, w której

71 Relatio Synodi III Nadzwyczajnego Zgromadzenia Ogólnego Synodu Biskupów, n. 33 .

72 Jan Paweł II, Evangelium vitae, n. 29.

73 Ibidem, n. 93. 
równi usługują równym. Wtedy bowiem sami małżonkowie podejmują zadanie apostolskie względem innych małżonków ${ }^{74}$, dzieląc się tym jak żyć i głosić Ewangelię życia i miłości, która prowadzi do życia wiecznego. Jak uczył Jan Paweł II, życie wieczne jest życiem samego Boga i „życiem synów Bożych”. Wobec nieogarnionej prawdy, która przychodzi do nas od Boga w Chrystusie, reakcją wierzącego musi być niesłabnące zdumienie i bezgraniczna wdzięczność. W ten sposób osiąga swój szczyt chrześcijańska prawda o życiu. Godność życia nie wynika jedynie z jego źródeł, czyli z faktu, że pochodzi ono od Boga, ale także $z$ jego celu, z jego przeznaczenia do komunii z Bogiem przez poznanie Go i umiłowanie. Wynikają stąd bezpośrednie konsekwencje dla życia człowieka nawet w jego ziemskiej kondycji, w której już zakiełkowało i wzrasta życie wieczne. Człowiek instynktownie miłuje życie, bo jest ono dobrem. Miłość do życia, jaką ma każda istota ludzka, nie ogranicza się do zwykłego szukania przestrzeni pozwalającej na realizowanie siebie i na nawiązanie stosunków z innymi, ale rozwija się w radosnym przeświadczeniu, że można uczynić z własnej egzystencji „miejsce” objawienia się Boga, spotkania i komunii z Nim ${ }^{75}$.

Od Chrystusa za pośrednictwem Kościoła, małżeństwo i rodzina otrzymują niezbędną łaskę do świadczenia o miłości Boga i życia życiem komunii. Ewangelia rodziny przenika historię świata od stworzenia człowieka na obraz i podobieństwo Boga ( $R d z$ 1, 26-27), aż do wypełnienia tajemnicy Przymierza w Chrystusie na końcu czasów ${ }^{76}$.

Zadanie głoszenia tej Ewangelii spoczywa na wszystkich, którzy jej doświadczyli i pragną nią żyć na co dzień nie zachowując jej tylko dla siebie, ale pragnąe podzielić się z innymi. „Chodzi o doświadczenie, że Ewangelia rodziny jest radością, która napełnia serce i całe życie człowieka, gdyż wyzwala z grzechu, smutku, z wewnętrznej pustki"77 i prowadzi do spotkania z Życiem - Jezusem Chrystusem. Głoszenie Ewangelii życia jest fundamentem przywrócenia godności ludzkiego życia. Proponowany przez Ewangelię jednoznaczny i pełny sens życia ludzkiego jest najlepszym środkiem zaradczym na choroby współczesnego świata i utratę sensu i wartości ludzkiego życia ${ }^{78}$. Głoszenie Ewangelii

$74 \quad$ Paweł VI, Humanae vitae, n. 26.

75 Jan Paweł II, Evangelium vitae, n. 38.

Relatio Synodi III Nadzwyczajnego Zgromadzenia Ogólnego Synodu Biskupów, n. 16.

77 Franciszek, Evangelii gaudium, n. 1; Por. Relatio Synodi III Nadzwyczajnego Zgromadzenia Ogólnego Synodu Biskupów, n. 31. 
rodziny jest wobec wyzwań współczesnego świata pilną potrzebą nowej ewangelizacji. Kościół jest tego świadom i chce to czynić wespół z chrześcijańskimi rodzinami ${ }^{79}$, które będą o niej świadczyć życiem, ale też „wyznawać ustami”. Wiara oznacza bowiem zaangażowanie i publiczne świadectwo. Chrześcijanin nigdy nie może myśleć, że wiara jest sprawą prywatną. Wiara jest decyzją na to, żeby być z Panem, aby z Nim żyć. To „,bycie z Nim” wprowadza do zrozumienia powodów, dla których się wierzy. Wiara jest aktem wolności i miłości. Wymaga więc odpowiedzialności społecznej za to, w co się wierzy. A obdarzeni darem Ducha Świętego, który uzdalnia do misji i umacnia świadectwo, czyni je śmiałym i odważnym ${ }^{80}$, rodziny głoszą ją z radością i wdzięcznością, że wcześniej sami mogli ją usłyszeć, przyjąć i nią żyć.

Słowa kluczowe: małżeństwo, rodzina, miłość, życie, Ewangelia, misja, społeczeństwo.

\section{Bibliografia:}

1. Benedykt XVI, Deus caritas est (25.12.2005).

2. Benedykt XVI, Porta fidei (11.10.2011).

3. Franciszek, Lumen fidei (29.06.2013).

4. Franciszek, Evangelii gaudium (24.11.2013).

5. Jan Paweł II, Redemptor hominis (04.03.1979).

6. Jan Paweł II, Familiaris consortio (22.11.1981).

7. Jan Paweł II, List do rodzin (02.02.1994).

8. Jan Paweł II, Evangelium vitae (25.03.1995).

9. Jan Paweł II, List do osób w podeszłym wieku (01.10.1999).

10. Karta Praw Rodziny (22.10.1983).

11. Paweł VI, Humanae vitae (25.07.1968).

12. Papieska Rada ds. Rodziny, Przygotowanie do sakramentu matżeństwa (13.05.1996).

13. Papieska Rada ds. Rodziny, Vademecum dla spowiedników (12.02.1997), [w:] W trosce o dobro matżeństwa i rodziny, t. 1, Dokumenty Papieskiej Rady ds. Rodziny, Lublin 2010.

14. Papieska Rada ds. Rodziny, Rodzina matżeństwo i „wolne zwiazki” (26.07.2000), [w:] W trosce o dobro matzeństwa i rodziny, t. 1, Dokumenty Papieskiej Rady ds. Rodziny, Lublin 2010.

15. Relatio Synodi III Nadzwyczajnego Zgromadzenia Ogólnego Synodu Biskupów (18.10.2014), w: http://episkopat.pl/dokumenty/6230.1,quot_Relatio_Synodi_quot_III_Nadzwyczajnego_Zgromadzenia_Ogolnego_Synodu_Biskupow.html (05.11.2011).

Relatio Synodi III Nadzwyczajnego Zgromadzenia Ogólnego Synodu Biskupów, n. 29.

80 Benedykt XVI, Porta fidei, n. 10. 